\title{
Study on the Cultivation of Observation Ability of Secondary School Students
}

\author{
Shuang Yu and Guang Li * \\ College of Resource and Environment, Anshun University, Anshun 561000 \\ * The Corresponding Author
}

Keywords: Teaching in the middle school; Observation ability; Experiment; Method

\begin{abstract}
Cultivating students' observation ability is an important part of teaching in middle schools and a basic ability for students to learn. It has a special role in cultivating students' creative ability. Training students' observation ability can be started from several aspects: teaching students extensively collecting and selecting observation materials, learning to use observation tools, guiding students to observe the graphics in teaching materials in the classroom, and applying modern teaching methods to improve students' cognitive level. Strengthen extracurricular practice.
\end{abstract}

\section{Introduction}

Observation is one of the traditional methods of research. From the perspective of epistemology, observation can obtain first-hand perceptual materials. Observing ability refers to the ability to fully and correctly understand the characteristics of things by observing activities. Observation is an important part of teaching and it is the basic ability for learning. The level of observational power not only directly relates to the pros and cons of students mastering knowledge, but also relates to the development of students' thinking ability and creative ability. For example, Darwin, the founder of the evolution theory, has amazing observation ability and something easily overlooked by others. However, he can observe very carefully. This comes from his long and arduous observation of nature. For another example, the father of modern biology, Pavlov, takes "observation and observation and observation" as the motto and strictly demands himself. This shows that in the teaching of middle school, how to cultivate students' observation ability is an important aspect of teaching reform. So how to train students' observation ability in teaching? Can be carried out from the following aspects.

\section{Train Students' Observation Ability in Classroom Teaching}

Use the Models, Illustrations and Wall Charts, Live Organisms, and Specimens in the Textbooks to Develop Students' Observation Ability. Wall charts and models are commonly used visual teaching aids in teaching. He and the illustrations in the textbooks are based on the main contents of the teaching materials and are difficult to draw. They have the characteristics of close cooperation with teaching materials, vividness, image, and strong visibility. Using models, flipcharts, and illustrations for teaching can fully mobilize students' active coordination of audio-visual senses and brain thinking. The abstract thinking of Huawei image thinking not only enables students to understand textbooks well, but also enables students to remember and judge their abilities. And observation ability is cultivated and improved.

The use of wall charts, models and illustrations in teaching is to ensure the accuracy of observations and classroom effects. Attention should be paid to the following three points: First, when preparing lessons, we must fully study the content of the teaching materials and diagrams so that the thumbnails are correct and rigorous. Guide students to observe correctly. The second is to specifically guide the observation method. Ask the students to look at the map and clearly explain the symbols, structure names, and slice positions. The third is to show the map or model time is appropriate, not too early or too late, so as not to distract the students' attention. 
Through the Demonstration Experiment, Develop Students' Observation Ability. Demonstration experiment is an intuitive teaching method that deepens students' perceptual knowledge. It is also an effective way to cultivate students' observation ability. When teachers are conducting demonstration labs, students can only obtain a perceptual understanding of things and lay the foundation for mastering teaching materials.

Of course, in addition to the above two methods in class, many modern teaching methods such as multimedia, video, and slides can also be used to cultivate students' observation ability. No matter which method you use, you should inspire students to think positively in the observation process and see the essence through phenomena.

\section{To Develop Students' Observation Ability Through the Experiment}

Scientific concepts, principles, and laws are derived from experimental derivation and demonstration. Experiments in the teaching process help deepen the understanding of natural science concepts, principles, and laws. In the experiment, students must observe, listen, smell, touch and observe all kinds of phenomena comprehensively. Therefore, experiment is the main way to develop students' observation ability. In the course of the experiment, for each observation content, students are first allowed to observe and think independently under the guidance of the teacher, and then they are summarized through student reading materials or teachers using conversation and telling methods. Teachers must know that students not only use the senses and tools to "see", but also use the brain to "inspect", to analyze, compare and judge the observed phenomena, to obtain correct results through thinking, and to make "intuitive observation". Sublimation is "logical observation." The key to improving the observation ability lies in the correct observation procedures and scientific observation methods. To teach students to observe in the right way is necessary to cultivate students' observation ability.

\section{To Develop Students' Observation Ability Through the Extracurricular Activities and Field Observations}

Extracurricular activities contribute to the development of students' observational skills and can achieve the effects of learning to apply. In teaching, teachers can often use their spare time and holidays to organize students to conduct extracurricular activities and conduct field observations. Of course, teachers must organize carefully, have a clear purpose and specific requirements to enable students to avoid observing the blindness of the observation, the teacher should also guide students to make detailed records of the basic morphology of the biological characteristics in order to prepare for classroom learning. In this process, students are allowed to learn how to make simple specimens and develop students' ability to use their brains. In extra-curricular activities and field observations, students can observe a large number of sensible materials by collecting and making animal and plant specimens, planting plants, raising animals, and ecological surveys. This not only expands students' knowledge horizons, but also cultivates students' knowledge. Observe interest and observe ability. In particular, field observations can also cultivate students' sentiments and enable them to love nature and enhance their awareness of protecting nature. Therefore, extracurricular activities and field trips are another important way to cultivate students' observation ability. For example: students observe the frog's growth and development process, understand the frog's life history and abnormal development, and deepen the understanding of theoretical knowledge.

We organized extra-curricular activities to organize students to participate in a variety of extra-curricular activities, strengthened the cultivation of students' experimental and observational skills, improved students' enthusiasm and initiative in exploring scientific mysteries, and inspired students to love nature, love science, and care for ecology. The beautiful emotions of the environment. It can be said to be more than one! 


\section{Observing Interest in Training Observation Ability}

Interest is a good friend of observation and one of the prerequisites for cultivating student observation skills. Teachers can introduce interesting life phenomena to students, conduct extra-curricular activities, conduct field trips, visit zoos, botanical gardens, and museums to stimulate students' interest in observation. Students often have a sense of accomplishment, which is also reflected in observations. When the observations are successful, they have a lot of interest; on the contrary, they are uncomfortable. In observation, teachers must work hard to create conditions for the student's observation to succeed in order to enhance their observational interest. In addition, traditional observational experiments are often verifiable, and students only follow the prescribed steps for expected observations. In observing activities, there is not much content involving the "student subject". For students with strong curiosity, watching interest will be affected. If the teacher takes the student as the main subject, he uses an exploratory method to set up suspicion and guide observations so that the student can succeed in solving the doubt. This will greatly increase students' interest in observation.

\section{Matters Needing Attention for Teachers in the Process of Training Students' Observation Ability}

Regardless of the ways and methods used to develop students' observational skills, pay attention to the following three points. First of all, observation should have a clear purpose. Observation is a very purposeful activity. When a person performs a perceptive activity, if there is no clear purpose, it can only be called a general perception, and cannot be called observation; only a perceptive activity with a clear purpose can be called observation. Second, observation must have a scientific attitude. Seeking truth from facts is an important scientific quality necessary for correct observation. When teachers develop students' observation ability, teachers should require students to observe the actual situation when they are observing records, drawing observation charts, and describing phenomena objects. In the end, observations must be organized. Observing makes a complicated and meticulous activity, and casually and unstructured, it is absolutely not effective. Therefore, to cultivate observation ability, we must pay attention to the rationality of observation, so as to increase the speed and correctness of observation.

People realize that objective things are always achieved through a series of psychological activities such as feelings and intuition. Observing is a special form of perception. It is an intuition process with a certain purpose, task, plan, and targeted understanding of the surrounding things. The level of student's ability to observe not only affects their enthusiasm and initiative when they learn, but also determines whether they can discover, invent, and create when they go to society. Obviously, training observation ability is very important for creating talents.

\section{References}

[1] Borich, G. D. (2016). Observation skills for effective teaching: research-based practice. Routledge.

[2] Watts, T. W., Duncan, G. J., Siegler, R. S., \& Davis-Kean, P. E. (2014). What's past is prologue: Relations between early mathematics knowledge and high school achievement. Educational Researcher, 43(7), 352-360.

[3] Bowe, R., Ball, S. J., \& Gold, A. (2017). Reforming education and changing schools: Case studies in policy sociology (Vol. 10). Routledge.

[4] Zeidan, A. H., \& Jayosi, M. R. (2015). Science Process Skills and Attitudes toward Science among Palestinian Secondary School Students. World journal of Education, 5(1), 13-24.

[5] Ismail, S., Bitsuamlak, H., \& Alemu, K. (2017). High risk sexual behaviours for STD/HIV, pregnancies and contraception among high school students in a rural town, north western Ethiopia. The Ethiopian Journal of Health Development (EJHD), 11(1).

[6] Swanson, E., Wanzek, J., McCulley, L., Stillman-Spisak, S., Vaughn, S., Simmons, D., ... \& 
Hairrell, A. (2016). Literacy and text reading in middle and high school social studies and English language arts classrooms. Reading \& Writing Quarterly, 32(3), 199-222.

[7] Borich, G. D. (2016). Observation skills for effective teaching: research-based practice. Routledge.

[8] Gregory, A., Allen, J. P., Mikami, A. Y., Hafen, C. A., \& Pianta, R. C. (2014). Effects of a professional development program on behavioral engagement of students in middle and high school. Psychology in the Schools, 51(2), 143-163.

[9] Elert, N., Andersson, F. W., \& Wennberg, K. (2015). The impact of entrepreneurship education in high school on long-term entrepreneurial performance. Journal of Economic Behavior \& Organization, 111, 209-223.

[10] Ary, D., Jacobs, L. C., Irvine, C. K. S., \& Walker, D. (2018). Introduction to research in education. Cengage Learning. 